\title{
Features of Effective T Cell-Inducing Vaccines against Chronic Viral Infections
}

\author{
Eleni Panagioti ${ }^{1,2}$, Paul Klenerman', Lian N. Lee ${ }^{3}$, Sjoerd H. van der Burg ${ }^{1}$ \\ and Ramon Arens ${ }^{2 *}$
}

${ }^{1}$ Department of Medical Oncology, Leiden University Medical Center, Leiden, Netherlands, ${ }^{2}$ Department of Immunohematology and Blood Transfusion, Leiden University Medical Center, Leiden, Netherlands,

${ }^{3}$ Nuffield Department of Medicine, University of Oxford, Oxford, United Kingdom

\section{OPEN ACCESS}

Edited by:

Maria Florencia Quiroga, Universidad de Buenos Aires, Argentina

Reviewed by: John J. Miles,

James Cook University, Australia

Maria Magdalena Gherardi, Consejo Nacional de Investigaciones Cientificas y Técnicas (CONICET), Argentina

*Correspondence: Ramon Arens r.arens@/umc.n

Specialty section: This article was submitted to T Cell Biology,

a section of the journal

Frontiers in Immunology

Received: 21 November 2017 Accepted: 31 January 2018 Published: 16 February 2018

Citation:

Panagioti E, Klenerman P, Lee LN, van der Burg SH and Arens R (2018)

Features of Effective T Cell-Inducing

Vaccines against Chronic Viral Infections.

Front. Immunol. 9:276. doi: 10.3389/fimmu.2018.00276
For many years, the focus of prophylactic vaccines was to elicit neutralizing antibodies, but it has become increasingly evident that $T$ cell-mediated immunity plays a central role in controlling persistent viral infections such as with human immunodeficiency virus, cytomegalovirus, and hepatitis C virus. Currently, various promising prophylactic vaccines, capable of inducing substantial vaccine-specific $T$ cell responses, are investigated in preclinical and clinical studies. There is compelling evidence that protection by $T$ cells is related to the magnitude and breadth of the $T$ cell response, the type and homing properties of the memory $T$ cell subsets, and their cytokine polyfunctionality and metabolic fitness. In this review, we evaluated these key factors that determine the qualitative and quantitative properties of $\mathrm{CD} 4^{+}$and $\mathrm{CD}^{+} \mathrm{T}$ cell responses in the context of chronic viral disease and prophylactic vaccine development. Elucidation of the mechanisms underlying $T$ cell-mediated protection against chronic viral pathogens will facilitate the development of more potent, durable and safe prophylactic T cell-based vaccines.

Keywords: T cells, quality, vaccine, prophylaxis, chronic infection, virus

\section{INTRODUCTION}

Our bodies are persistently exposed to various pathogens present in the environment. The immune system is fortified with physical barriers and with diverse immune cell populations that play an integral role in protection against disease. Long-term immune responses are mediated by antigenspecific lymphocytes and antibodies that are formed upon pathogen entry. Memory B and T cells are numerically and functionally superior to their naïve precursors cells that are present before infection, and upon encounter with the same pathogen memory immune cells are able to induce a more rapid and powerful recall response (i.e., immunological memory) $(1,2)$.

The majority of prophylactic vaccines against viral infections have focused on the induction of neutralizing antibodies. Indeed, potent antibody inducing vaccines against virally induced diseases are available. Nevertheless, they fail to provide long-term efficacy and protection against a number of chronic viral infections. Studies in mice, non-human primates, and humans provide evidence that effective prophylactic vaccines against chronic (low level and high level) replicating viruses [i.e., herpesviruses, human immunodeficiency virus (HIV), and hepatitis C virus (HCV)] should engage strong cellular $\mathrm{T}$ cell immunity (3-5). The development of $\mathrm{T}$ cell-eliciting prophylactic vaccines has gained increasing attention, although such vaccines are not always able to provide 
sterilizing immunity. Despite various promising vaccines that are capable of stimulating robust $\mathrm{T}$ cell responses, the critical factors of $\mathrm{T}$ cell-mediated immune protection against these chronic infections have not been clearly defined. Often, the memory response provoked by vaccines is not sustained and frequently diminishes over time $(6,7)$. Thus, more knowledge is required to tailor the vaccine's capacity to induce durable $\mathrm{CD}^{+}$and/or $\mathrm{CD}^{+} \mathrm{T}$ cell responses of appropriate magnitude and quality to effectively contribute to pathogen clearance. Elucidating the mechanisms through which antigen-specific $\mathrm{T}$ cell populations mediate long-term protection against viruses at body surfaces and (lymphoid) tissues remains an important goal, and will facilitate the development of more effective and safe prophylactic $\mathrm{T}$ cell-eliciting vaccines. Here, we review determinants and mechanistic factors of effective $\mathrm{T}$ cell populations implicated in the vaccine efficacy against chronic viral infections, and discuss how this knowledge can be utilized to maximize the possibility of creating effective vaccine platforms for persistent viral infections.

\section{THE COMPLEXITY OF THE ANTIGEN- SPECIFIC T CELL RESPONSE DURING INFECTION}

The antigen-specific interactions between T cells and DCs resulting in activation may initially be short lived, before stabilizing and may last up to $12 \mathrm{~h}$. During this period, T cells receive their necessary activating signals $(8,9)$. For proper activation of naïve $\mathrm{CD}^{+}$and $\mathrm{CD}^{+} \mathrm{T}$ cells, cognate antigenic signals through the TCR (signal 1), costimulatory signals (signal 2) and signals provided by inflammatory cytokines (signal 3 ) are required (10, 11). Expression of particular chemokine receptors such as CCL19 and CCL2 1 enhance immune responses by stimulating the interactions between $\mathrm{T}$ cells and DCs during antigen presentation (12-15). In addition, the secretion of chemokines by activated DCs and $\mathrm{CD}^{+} \mathrm{T}$ cells enhances $\mathrm{CD} 8^{+} \mathrm{T}$ cell accumulation and help attract rare antigen-specific T cells $(16,17)$. The activation of $\mathrm{T}$ cells results in alteration of the expression of various molecules including integrins, selectins, and chemokine receptors, leading to the modulation of key intracellular signaling events that promote proliferation, differentiation, and migration of $\mathrm{T}$ cells to inflamed tissues (18-20).

After resolution of the infection, the majority (90-95\%) of the effector T cells are eliminated due to programmed cell death and only a small, yet diverse pool of memory cells remains (21, 22). Traditionally, memory $\mathrm{T}$ cells were classified into two major categories based on their proliferation capacity, phenotypic features, and migration potential (23). Effector-memory $\mathrm{T}$ $\left(\mathrm{T}_{\mathrm{EM}}\right)$ cells are identified based on combined expression and/or lack of certain cell surface markers including KLRG $1^{\text {hi }} / \mathrm{CD} 44^{\text {hi }} /$ $\mathrm{CD} 127^{\mathrm{lo}} / \mathrm{CD} 6 \mathrm{~L}^{\mathrm{lo}}$. These cells have limited proliferation capacity upon TCR triggering but rapidly produce effector molecules and cytokines such as IFN- $\gamma$ and $\operatorname{TNF}(24,25)$. Central-memory $\mathrm{T}\left(\mathrm{T}_{\mathrm{CM}}\right)$ cells are distinguished by the expression of $\mathrm{KLRG}^{\mathrm{lo}} /$ CD $44^{\text {hi }} / \mathrm{CD} 127^{\mathrm{hi}} / \mathrm{CD} 62 \mathrm{~L}^{\mathrm{hi}}$ surface markers, exhibit a superior proliferation capacity and produce cytokines that are directly associated with better secondary expansion such as interleukin
(IL)-2. Secondary lymphoid organs are the main homing sites of $\mathrm{T}_{\mathrm{CM}}$ cells whereas $\mathrm{T}_{\mathrm{EM}}$ cells are more dominantly present in (nonlymphoid) tissues (26-29). Both $\mathrm{T}_{\mathrm{CM}}$ and $\mathrm{T}_{\mathrm{EM}}$ cells can circulate, whereas a recently discovered new category of $\mathrm{T}$ cells present in tissues lacks migratory capacity. These cells, named tissueresident memory $\mathrm{T}\left(\mathrm{T}_{\mathrm{RM}}\right)$ cells, permanently reside in peripheral tissues, even after the infection is cleared. $\mathrm{T}_{\mathrm{RM}}$ cells are present in most organs and tissues and can be defined based on the expression of CD69 ${ }^{\text {hi }} / \mathrm{CD} 62 \mathrm{~L}^{\mathrm{lo}} / \mathrm{CD} 44^{\mathrm{hi}}$ and other surface markers (e.g., CD11a, CD38, CD49a, CD103, and CXCR3) (30-33). However, the composition of these markers depends on tissue-specific cues, and expression levels vary in different tissues. Besides these three main memory $\mathrm{T}$ cell subsets, a small subset of memory $\mathrm{T}$ cells exists that exhibit advanced stem cell like qualities and proliferation capacities compared with other T cell subsets (34). These memory T cells, which were designated stem cell memory T cells ( $\mathrm{T}_{\mathrm{SCM}}$ cells), display a phenotype highly similar to naive $\mathrm{T}$ cells ( $\mathrm{T}_{\mathrm{N}}$ cells), being $\mathrm{KLRG}^{\mathrm{lo}} / \mathrm{CD} 44^{\mathrm{lo}} / \mathrm{CD} 127^{\mathrm{hi}} / \mathrm{CD} 2^{\mathrm{Li}} / \mathrm{CD} 69^{\mathrm{lo}}$, but also co-express stem cell antigen (Sca-1), the $\beta$ chain of the IL-2 and IL-15 receptor (CD122 and IL-2R $\beta$ ), and the chemokine receptor CXCR3 (34-39). Some studies reported that T cells with an early stage of differentiation can be induced by vaccines (40, 41) but whether this induction is important for vaccine efficacy is unclear. Thus, whether sufficient amounts of $\mathrm{T}_{\mathrm{SCM}}$-like $\mathrm{T}$ cells able to elicit protection can be generated by vaccines needs further exploration. Notably, humans and mice have broadly analogous $\mathrm{T}$ cell biology, and the above described subsets (i.e., $\mathrm{T}_{\mathrm{CM}}, \mathrm{T}_{\mathrm{EM}}, \mathrm{T}_{\mathrm{RM}}$, and $\mathrm{T}_{\mathrm{SCM}}$ cells) have been described in both species and share similar characteristics.

Live attenuated as well as synthetic or subunit vaccines are able to elicit $\mathrm{T}_{\mathrm{CM}}, \mathrm{T}_{\mathrm{EM}}$, and $\mathrm{T}_{\mathrm{RM}}$ cells $(30,32)$. With respect to live attenuated vaccines, the vaccine-induced $T$ cell subsets can be highly similar to those subsets that develop upon infection (42). However, live vaccines have disadvantages (e.g., transformation to a virulent form and requires refrigeration), which prompts the development of inactivated, synthetic, or subunit vaccines. T cell subsets that develop upon immunization with those vaccines are highly dependent on the addition of adjuvants and on the route of administration (43).

\section{THE MAGNITUDE OF THE T CELL RESPONSE IS IMPORTANT FOR OPTIMAL PROTECTION}

The magnitude of viral-specific $\mathrm{T}$ cell responses is highly dictated by the infectious dose and route of infection (44). Higher infectious dosages lead generally to higher peak values of effector $\mathrm{T}$ cells, and correspondingly larger amounts of memory $\mathrm{T}$ cells in the circulation are found. However, if the immune system is overwhelmed and virus replication remains at a high level, this eventually leads to exhaustion of T cells and poor memory formation (45).

Given the frequently observed correlation between the magnitude of $\mathrm{T}$ cell responses and establishment of immunity during infections, simply determining the magnitude of the vaccineelicited $\mathrm{T}$ cell response may already serve as a predictor of efficacy 
in vaccination settings. A number of studies have shown a direct association between the vaccine-elicited $\mathrm{T}$ cell response size and the ability for virus control $(5,46-48)$. Several parameters directly impact the magnitude of the vaccine-induced $\mathrm{T}$ cell response. In the case of live (attenuated) viruses, the size of the initial dose of the inoculum correlates to the magnitude of the vaccinespecific T cell response until a threshold is reached (49). To reach similar levels as that elicited by virulent virus, inoculum sizes are generally higher for replication-deficient or single-cycle viral vectors. For synthetic vaccines, however, the saturation threshold may not be reached because of lack of sufficient inflammatory signals. However, recent discoveries in adjuvant development and synthetic (nano)particles provide promising approaches to augment $\mathrm{T}$ cell responses (50-52). Besides the initial inoculum dosage, booster vaccine regimens increase the magnitude of the T cell response $(43,53,54)$ and are likely essential for the majority of vaccine platforms including live vaccines (55). In this regard, vaccines that prime with DNA or adenoviral vectors and boost with modified vaccinia Ankara are excellent demonstrations that underline the supremacy of prime-boost vaccination regimens $(4,56-64)$.

\section{MEMORY T CELL INFLATION PROVOKED BY RECOMBINANT VACCINES}

An alternative mechanism leading to a durable increased magnitude of memory T cells, described as memory "inflation" $(65,66)$, is observed for certain viral-specific responses following infection by cytomegalovirus (CMV). Here, antigen-specific T cells specific to a subset of viral peptides show an unusual response, whereby they expand gradually over time and are maintained at high frequencies as $\mathrm{T}_{\mathrm{EM}}$-like populations-as opposed to the standard expansion and contraction kinetic of conventional memory cells. Critically, and unlike exhausted CD8 T cells that develop during other persistent infections these inflationary responses maintain their effector functions, tissue homing ability and can provide protection against pathogen rechallenge. Memory inflation has also been observed for CMV-specific antibodies, whose levels gradually increase over time (67). Although the rules that determine the onset of memory inflation have not been fully defined, it is clear that for inflation to occur viral antigen must persist long term, a criterion fulfilled by CMV infection through periodic episodes of reactivation from its latent state. Memory $\mathrm{T}$ cell inflation appears to require $\mathrm{T}$ cell costimulation $(68,69)$, yet is less dependent on the immunoproteasome (70). Modifying the context of the peptide can convert a classical response to an inflationary one (71).

Recombinant CMVs may provide important vectors for vaccines, although they are highly complex viruses containing multiple immune evasion genes. Nevertheless, in experimental models engineered mouse cytomegalovirus (MCMV)-based vaccine vectors containing foreign viral sequences (e.g., derived from influenza virus, lymphocytic choriomeningitis virus, Ebola virus, herpes simplex virus, and respiratory syncytial virus) provide long-lasting protection $(42,71-73)$. In rhesus macaques, a recombinant $\mathrm{CMV}$ vector expressing simian immunodeficiency virus (SIV) antigens induced in addition to $\mathrm{MHC}$ class I-restricted $\mathrm{CD}^{+} \mathrm{T}$ cell responses also MHC class II-restricted and HLA-Erestricted $\mathrm{CD}^{+} \mathrm{T}$ cell responses $(74,75)$. These unconventional responses are likely to arise because of the restrictions placed on normal antigen presentation by the attenuated CMV vectors used. More work is needed to identify which of these populations is critical for protection, and whether this protection correlates to magnitude, breadth, or effector mechanism.

Memory inflation is not exclusively induced by CMV. Similar phenomena have been observed with other viruses, e.g., Epstein-Barr virus (EBV), herpes simplex virus-1, parvovirus $\mathrm{B} 19$, murine polyoma virus, and adenoviral vectors $(66,76)$. The latter is of interest with respect to vaccine-induced responses. In mouse models, adenovirus-based vectors can lead to induction of inflationary responses, which closely resemble those induced by natural CMV infections $(77,78)$. Moreover, in this vaccine platform, it is possible to generate inflationary responses against otherwise non-inflationary epitopes by constructing "minigenes," in which only the CD8 T cell epitope of interest is inserted into the vector and expressed, thus bypassing antigen processing requirements (79). Adenoviral vectored vaccines have been developed against many pathogens, including EBV, HCV, HIV, malaria, and Ebola $(4,64,80-82)$, and the responses elicited by these vectors in human volunteers are sustained over time. The HCV-specific responses induced in healthy $\mathrm{CMV}^{+}$volunteers after immunization with a chimpanzee adenovectored-HCV vaccine shared similar phenotype and functionality to their CMV-specific memory populations as well as to inflating memory cells induced after AdHu5 and MCMV infection in mice (78).

\section{THE BREADTH OF THE INDUCED T CELL RESPONSE IMPACTS ON PROTECTION}

An increased breadth of the vaccine-induced $\mathrm{T}$ cell response has been found beneficial against many chronic viral pathogens (5, 54, 83-86). Induction of $\mathrm{T}$ cells with multiple antigenspecificities correlates with advanced killing capacity for control of $\mathrm{HCV}$ or even complete eradication during primary infection with HCV and superior protection upon reinfection $(80,86,87)$. Analysis of $\mathrm{CD}^{+} \mathrm{T}$ cell responses in untreated $\mathrm{HIV}$-infected individuals showed that an increasing breadth of Gag-specific responses is associated with decreased viremia (88).

Successful induction of potent and broad $\mathrm{T}$ cell responses has been reported for DNA plasmid vaccines $(89,90)$ and adenovirus serotype 26 vector-based vaccines (91). The latter approach incorporated a combination of subdominant and dominant epitopes of rhesus macaques SIV in prime-boost vaccination schedules. In parallel with these findings, the efficacy of synthetic long peptide (SLP)-based vaccines to protect against MCMV was significantly improved by combinations of SLPs that increased the breadth of the antigen-specific $\mathrm{T}$ cell response (5). These findings indicate that cytotoxic $\mathrm{CD}^{+} \mathrm{T}$ cell populations consisting of a broad repertoire of specificities are better capable to effectively kill virus-infected cells compared with $\mathrm{T}$ cell pools with a single specificity. Possible explanations are that T cells of diverse specificity results in enhanced killing of virus-infected 
cells (compared with $\mathrm{T}$ cells with one specificity) or that viral escape mechanisms become restricted. Moreover, an increase in recognition of multiple epitopes may also contribute to protection against infection with heterologous viruses via cross-reactive responses (92). Vaccine efficacy is expected to be also dictated by the TCR clonotypes within a polyclonal antigen-specific T cell population, since immune escape during viral infection is linked to conserved TCR motifs while diverse clonotypic repertoires without discernible motifs are not associated with viral escape $(93,94)$. Hence, the importance of the diversity in the antigenspecific $\mathrm{T}$ cell repertoire (with respect to recognition of multiple antigens and diversity in clonotypes specific for the same epitope) should be taken into account while designing prophylactic $T$ cellbased vaccines.

As discussed earlier, both the magnitude and breadth of the $\mathrm{T}$ cell response is of importance. However, it should be noted that simply determining the magnitude in the blood is not always valuable, as vaccine efficacy depends also on the type of memory $\mathrm{T}$ cell and its location. For example, a direct association between protection and the frequency of the $\mathrm{T}$ cells in the circulation does not always exist (95). Actually, depending on the route of infection, $\mathrm{T}$ cells present in the mucosal surfaces or in the tissues $\left(\mathrm{T}_{\mathrm{EM}}\right.$ and/or $\left.\mathrm{T}_{\mathrm{RM}}\right)$ play a dominant role in controlling the infection, and sufficient numbers in these areas rather than in the circulation are likely required to form a robust frontline defense against, e.g., HIV-1 (30, 96). Competition between antigens (e.g., the cellular processing and presentation machinery) is also an important consideration (5), highlighting that antigen selection is not simply a case of "the more the better." Furthermore, not all antigen-specific $\mathrm{T}$ cell populations have the same efficacy on a per-cell basis. For example, T cell populations specific for CMV antigens that invoke inflationary responses show superior protective capacity (5). Selection of the correct but also the appropriate quantity of antigens will ultimately steer the immune response and is thus a very critical step of the vaccine development process. Especially, antigens provoking antigen-specific $T$ cell populations with enhanced magnitude, breadth, and diversity in the clonotypic repertoire should be tested and subsequently selected for inclusion when designing vaccine vectors or synthetic vaccines. Furthermore, there is evidence that, besides the quantity and breadth, specific features of antigen-specific $\mathrm{T}$ cell populations such as their cytokine polyfunctionality and metabolic properties are also of crucial importance for vaccine efficacy, and this will be further discussed in the next sections.

\section{CYTOKINE POLYFUNCTIONALITY OF T CELLS AS PARAMETER OF VACCINE EFFICACY}

Cytokine production is an important effector mechanism of T cell-mediated immunity. Upon most viral and bacterial infections protective $\mathrm{T}$ cell immunity consists of $\mathrm{CD} 4^{+}$and $\mathrm{CD} 8^{+}$ T cells with a "Th1" cytokine profile that is characterized by (co-) production of IFN- $\gamma$, TNF, and IL-2 (97).

The frequency of IFN- $\boldsymbol{\gamma}$-producing $\mathrm{T}$ cells has been widely used as a parameter to assess vaccine-induced responses. In terms of effector function, IFN- $\gamma$ has been shown to play a role in the clearance of various viral infections (98). However, there are many examples showing that the magnitude of the IFN- $\gamma$ secreting $\mathrm{T}$ cell response is not a sufficient immune correlate of protection. Single positive IFN- $\gamma$-producing T cells can comprise a relatively large fraction of the total cytokine-producing $\mathrm{CD} 4^{+}$and $\mathrm{CD} 8^{+}$ $\mathrm{T}$ cell population after immunization. However, such $\mathrm{T}$ cells have a limited capacity to be sustained as memory T cells (99). Hence, prophylactic vaccines that elicit a high proportion of single IFN$\gamma$-producing $\mathrm{T}$ cells would likely not be protective and provide a clear example for why the quality of the response is far more useful in assessing long-term protection than just measuring the frequency of IFN- $\gamma$-producing T cells. Instead, studies characterizing (vaccine-elicited) T cell responses against HIV, HBV, HCV, $\mathrm{CMV}$, influenza, and Leishmania revealed a strong correlation between the protection level and the induction of high frequencies of polyfunctional T cells [e.g., coproducing IFN- $\gamma$, TNF, and IL-2 $(4,80,100-107)]$. Importantly, some of these studies showed that measuring the magnitude of IFN- $\gamma$-producing $\mathrm{CD}^{+}$and $\mathrm{CD} 8^{+}$ $\mathrm{T}$ cells alone was not sufficient to predict protection, and provided evidence that measuring the quality of the $\mathrm{CD} 4^{+}$and $\mathrm{CD} 8^{+} \mathrm{T}$ cell response, vis-à-vis polyfunctional T cells, is required.

The supremacy of the polyfunctional $\mathrm{T}$ cells may relate to the superior survival properties of these cells $(81,99,108)$ and to a higher level of target killing (109). This may be related to a higher IFN- $\gamma$ production on a per-cell basis by polyfunctional cells compared with monofunctional cells (110), and to the capacity of TNF that is like IFN- $\gamma$ also capable of mediating the killing of virus-infected cells (111-113). Moreover, reciprocal production of IFN- $\gamma$ and TNF leads to synergistic actions (114).

Furthermore, the other cytokine in the panel, IL-2, is decisive as well. Studies analyzing the production of IL- 2 and IFN- $\gamma$ by CD $4^{+}$ and $\mathrm{CD}^{+} \mathrm{T}$ cells from individuals infected with HIV showed that long-term non-progressors, or individuals on anti-retroviral treatment, had increased frequencies of T cells expressing IL-2 only or both IL- 2 and IFN- $\gamma$, whereas individuals with high viral loads (progressors) have increased frequencies of $\mathrm{T}$ cells producing IFN- $\gamma$ only (95). Although IL-2 has no direct antiviral function, it promotes proliferation and secondary expansion of antigen-specific T cells (115-120). In addition, IL-2 increases expression of the effector molecules perforin and granzyme, which mediate cytolytic function $(121,122)$. IL-2 signals may also enhance NK cell activity that could contribute to the early control of infection following challenge (99, 123-126). Taken together, we conclude that cytokine polyfunctionality is of major importance for the efficacy of $\mathrm{T}$ cell-based vaccines (Figure 1), hence dissecting how cytokine polyfunctionality is regulated during the programming of $\mathrm{T}$ cells is of interest and may reveal potential strategies to improve vaccine-mounted $\mathrm{T}$ cell responses.

\section{IMPROVING VACCINATION BY TARGETING T CELL METABOLISM?}

The transition of naïve $\mathrm{T}$ cells to active effector cells and memory $\mathrm{T}$ cells involves dynamic and coordinated metabolic modifications (129). This reprogramming of the cellular metabolism is 


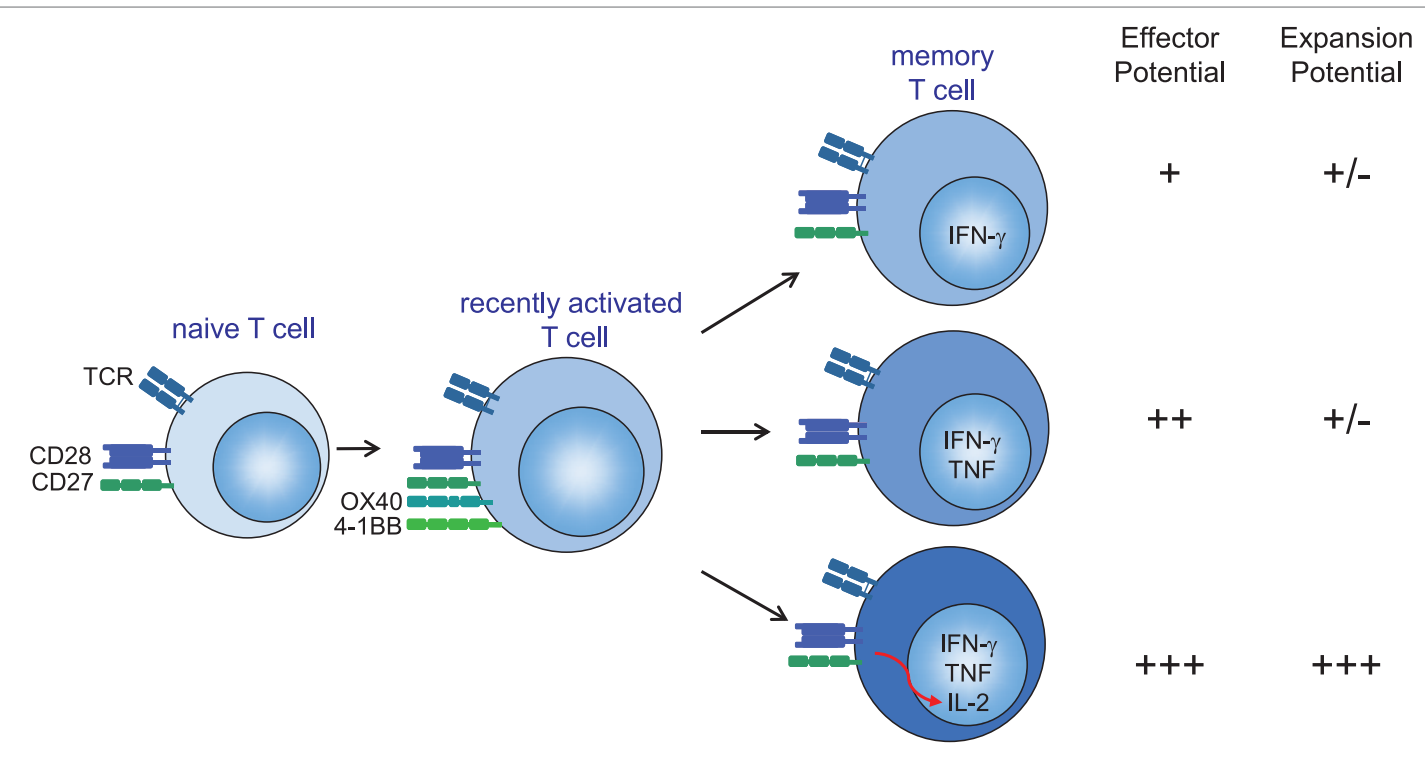

FIGURE 1 | Several mechanisms account for the optimal protection of (vaccine-elicited) polyfunctional cytokine-producing CD4+ and CD8 ${ }^{+} \mathrm{T}$ cells. (1) Secretion of more IFN- $\gamma$ on a per-cell basis. (2) T cells secreting both IFN- $\gamma$ and TNF have enhanced effector activity compared with T cells that secrete IFN- $\gamma$ alone. (3) Autocrine interleukin (IL)-2 production promotes the secondary expansion of memory T cells. Hence, IL-2, TNF, and IFN- $\gamma$ provide a relatively simple set of cytokines that can be used to define a vaccine-elicited response against specific infections that require $T$ cells for protection. CD28 signals are required for sufficient $\mathrm{T}$ cell priming during the primary phase of an infection, while OX40 (CD134) and 4-1BB (CD137) gain importance during the late effector and memory stages of antigen-specific T cells either by providing pro-survival signals or by enhancing the quality of the memory T cells (127, 128). CD27 stimulation is important during both early and late phases after infection (68). T cell costimulation via CD28 and tumor necrosis factor receptor family members (CD27, OX40, and 4-1BB) can provide signals to enhance autocrine IL-2 production.

not a consequence of activation but is linked to the differentiation and activation processes and reflects the fuel and substrates necessary to support the differentiation stages of a $\mathrm{T}$ cell $(130,131)$. Both naïve $\mathrm{T}$ cells and memory $\mathrm{T}$ cells rely primarily on oxidative phosphorylation (OXPHOS) and fatty acid oxidation (FAO) for fuel. This reflects the low level yet persistent need for energy as such cells are generally long-lived. Effector T cells on the other hand have particularly high energetic and synthesis demands. These cells have enhanced glycolysis and employ the mitochondrial tricarboxylic acid cycle to support their demand for de novo proteins, lipids, and nucleic acids synthesis. It is becoming increasingly clear that metabolic reprogramming plays a critical role in $\mathrm{T}$ cell activation, differentiation, and function. The distinct metabolic demands of different $\mathrm{T}$ cell subsets make them exquisitely sensitive to pharmacologic inhibitors of metabolism (132). These different metabolic requirements of T cell subsets provide us with a promising therapeutic opportunity to selectively tailor (vaccine-induced) immune responses. Thus, targeting $\mathrm{T}$ cell metabolism affords the opportunity to additionally regulate vaccine-induced responses.

Metabolic reprogramming occurs simultaneously with $\mathrm{T}$ cell activation and is facilitated by mTOR (mammalian target of rapamycin) (133). mTOR activation promotes glycolysis, fatty acid synthesis, and mitochondrial biogenesis. As such, targets upstream and downstream of the mTOR signaling pathway are potential therapeutic targets. Rapamycin, although known as an "immunosuppressive" drug due to its ability to slow down $\mathrm{T}$ cell proliferation, promote robust responses to vaccination by enhancing $\mathrm{CD}^{+} \mathrm{T}$ cell memory formation (134). Correspondingly, deletion of the mTORC1 inhibitory protein TSC2 leads to enhanced mTORC1 activity and increased effector function (135). Targeting of TSC2 or other molecules in the mTOR pathway might accordingly enhance immunity.

Targeting of glycolysis to inhibit immune responses in the setting of autoimmune disease and transplantation rejection is evolving, and this strategy is also used to enhance antitumor immunity by promoting long-lived memory cells ex vivo (136). Whether this can be used in vaccination strategies remains to be examined. Although most studies have focused on the critical role of glycolysis in promoting effector $\mathrm{T}$ cell generation and function, it has become clear that mitochondrial-directed metabolism also plays an important role. Memory T cells rely for their energy upon OXPHOS and FAO. Because these metabolic pathways are dependent on mitochondria, the abundance and the organization of the mitochondria are instrumental for development of fit memory cells (137). Alterations in the mitochondrial biogenesis can influence the differentiation of $\mathrm{T}$ cells, thereby providing opportunity to augment $\mathrm{T}$ cell-mediated immunity $(138,139)$. The transcription factor PGC1 $\alpha$ promotes mitochondrial biogenesis and function (140). Hence, pharmacologically or genetically enhancing PGC1 $\alpha$ represents a potential strategy for improving vaccine-induced $\mathrm{T}$ cell responses. In ex vivo systems, it has already been shown that enforced overexpression of PGC1 $\alpha$, leads to improved metabolic fitness and effector cytokine function of $\mathrm{CD}^{+} \mathrm{T}$ cells (141). Finally, the immediate uptake of amino acids such as glutamine and leucine is critical for proper 
metabolic reprogramming of T cells. This is accompanied with the upregulation of amino acid transporters involved in glutamine (SLC1A5) and leucine (SLC7A5/SLC3A2 heterodimer) (142, 143). Whether in vivo targeting of the above described metabolic processes is possible remains to be examined and may depend on the specificity of metabolic inhibitors/enhancers as they could affect many cells of the body. The future will tell if indeed metabolic targeting is possible to enhance vaccines. Nevertheless, the metabolic profiles of (vaccine-induced) T cells are surely of interest and correlate to vaccine-mediated immunity (144).

\section{COSTIMULATION EMPOWERS T CELL- ELICITING VACCINES}

Targeting costimulatory and inhibitory receptors on the cell surface of $\mathrm{T}$ cells has shown efficacy in various preventive and therapeutic preclinical vaccination settings. Costimulatory signals transduced via the CD28 family members CD28 and ICOS and via the tumor necrosis factor receptor (TNFR) family members CD27, 4-1BB, and OX40 play dominant roles in orchestrating the required "signal 2" for optimal $\mathrm{T}$ cell proliferation and survival (127). While CD28 and CD27 are constitutively expressed on naïve T cells, ICOS, 4-1BB, and OX40 are upregulated upon T cell activation $(127,145)$. Collaboration between costimulatory molecules was expected $(127,146)$ and confirmed in experimental models (147).

Enforced engagement of costimulatory molecules results in enhanced T cell activation, expansion, survival, and establishment of long-term memory (148-154), and has thus the potential to serve as effective immunomodulatory components of prophylactic vaccines against chronic viruses $(127,151,155)$. Indeed, this has already been observed for DNA and adenovirus-based vector vaccines in which enforced expression of costimulatory ligands stimulating CD27, 4-1BB, and OX40 leads to increased $\mathrm{T}$ cell expansion, enhanced cytotoxic activity and antibody responses $(156,157)$. Strikingly, agonistic antibodies to OX40 combined with synthetic peptide vaccines prompt robust effector and memory $\mathrm{CD}^{+}$and $\mathrm{CD}^{+}$antiviral $\mathrm{T}$ cell responses, thereby enhancing the prophylactic vaccine efficacy against lytic MCMV infection (153). Chronic viral infections are characterized by accumulation of functionally impaired antigen-specific $\mathrm{CD}^{+}$ T cells. Studies have shown that activation via 4-1BBL alone or in combination with CD80 can enhance the generation of primary $\mathrm{CD}^{+} \mathrm{T}$ cell responses and induce expansion of the antigenspecific $\mathrm{CD}^{+} \mathrm{T}$ cells from this pool of impaired T cells (145, 158). Similarly, 4-1BB stimulation has been shown to enhance the generation of primary CD8 ${ }^{+} \mathrm{T}$ cell responses $(148,159,160)$ and synergizes with attenuated vaccinia virus vectors to augment $\mathrm{CD}^{+} \mathrm{T}$ cell responses (148).

Targeting of inhibitory molecules on T cells, such as PD-1 and CTLA-4, has been shown to restore the effector function of (over) activated $\mathrm{T}$ cells in settings of chronic viral infections and cancer (161-164). Inhibitor blockade with monoclonal antibodies in combination with therapeutic vaccines synergizes in reinvigorating antitumor and antiviral T cell responses $(165,166)$. Targeting of inhibitory pathways during primary immunization with prophylactic vaccines may advance the vaccine efficacy as well $(167,168)$.

Although the use of antibodies targeting costimulatory and inhibitory molecules as immunostimulatory modalities in vaccine approaches can facilitate antigen-specific $\mathrm{T}$ cell responses, the use of such Abs, however, is associated with toxicity as demonstrated in rodents and in clinical settings (164, 169-171). Nevertheless, given the potential benefit to significantly increase the effectiveness of vaccines, both the efficacy and safety of targeting costimulation is currently extensively examined in various immunotherapeutic approaches against persistent viral infections. Examining the timing and/or the dosing is in this respect an important aspect, not only to prevent unwanted side effects but also to improve effectiveness. However, mass deployment of antibodies to improve vaccines may be too expensive, hence alternative methods able to target costimulatory and inhibitory molecules are desired.

CD28-mediated costimulation modulates T cell metabolism via activation of PI3K pathways, and this is essential to control effector cytokine production $(172,173)$. Moreover, CD28 signaling leads to PI3K-dependent upregulation of surface GLUT1 to facilitate enhanced glucose influx (172). This upregulation of GLUT1 is critical for T cell function, as genetic deletion of GLUT1 markedly inhibits effector T cells (174). Concomitant with increased expression of glucose transporters is the upregulation of key glycolytic enzymes (175). The inhibitory receptor PD-1 also regulates metabolic activity including glycolytic and mitochondrial processes $(139,176)$. TNFR family members are also able to metabolically program T cells $(177,178)$. Another important property of $\mathrm{T}$ cell costimulation is its effect on improving the T cell cytokine polyfunctionality. For example CD28 but also the TNFR family members are able to promote IL-2 production (153, 179-181), thereby directly improving the cytokine polyfunctionality (Figure 1). The TCR affinity also impacts polyfunctionality (182), and likely the collective signals of the TCR and costimulatory receptors are programming the polyfunctional status of T cells. In conclusion, targeting of T cell costimulation can impact the important quantitative (magnitude, breadth) and qualitative (cytokine polyfunctionality and metabolic fitness) determinants of vaccine-induced T cells, and provides thus major opportunities for further exploration in future vaccine designs.

\section{CONCLUSION AND PERSPECTIVES FOR VACCINE DESIGN}

The design of vaccines that imprint $\mathrm{T}$ cells with the ability to protect against persistent viral pathogens has gained remarkable progress. An understanding of the appropriate initial programming signals is a key step, as is how the route of priming or boosting influences the development of effective memory $\mathrm{T}$ cells. A combination of several metrics such as the type of the memory $\mathrm{T}$ cell, breadth, polyfunctional quality, and metabolic characteristics demonstrate a valid toolbox to define when a vaccine-elicited $\mathrm{T}$ cell response is protective. Information about the anatomic location, activation, and differentiation of memory $\mathrm{T}$ cells in lymphoid compared with non-lymphoid organs could 
be very valuable as well. Costimulatory signaling pathways mediate important $\mathrm{T}$ cell memory properties (e.g., programming of cytokine polyfunctionality and metabolism) and may serve as interesting targets for vaccine improvement. Insight into these pathways may identify the requisite pathways and potentially other targets to improve $\mathrm{T}$ cell-based immunotherapy. Coupling this to the identification of the best correlates of protection for persistent viral pathogens will foster the development of more effective vaccination regimes.

\section{REFERENCES}

1. Ahmed R, Gray D. Immunological memory and protective immunity: understanding their relation. Science (1996) 272:54-60. doi:10.1126/ science. 272.5258 .54

2. Berard M, Tough DF. Qualitative differences between naive and memory T cells. Immunology (2002) 106:127-38. doi:10.1046/j.1365-2567.2002.01447.x

3. Hansen SG, Ford JC, Lewis MS, Ventura AB, Hughes CM, Coyne-Johnson L, et al. Profound early control of highly pathogenic SIV by an effector memory T-cell vaccine. Nature (2011) 473:523-7. doi:10.1038/nature10003

4. Swadling L, Capone S, Antrobus RD, Brown A, Richardson R, Newell EW, et al. A human vaccine strategy based on chimpanzee adenoviral and MVA vectors that primes, boosts, and sustains functional HCV-specific $\mathrm{T}$ cell memory. Sci Transl Med (2014) 6:261 ra153. doi:10.1126/scitranslmed.3009185

5. Panagioti E, Redeker A, van Duikeren S, Franken KL, Drijfhout JW, van der Burg SH, et al. The breadth of synthetic long peptide vaccine-induced CD8+ T cell responses determines the efficacy against mouse cytomegalovirus infection. PLoS Pathog (2016) 12:e1005895. doi:10.1371/journal. ppat.1005895

6. Plotkin SA. Vaccines: correlates of vaccine-induced immunity. Clin Infect Dis (2008) 47:401-9. doi:10.1086/589862

7. Goronzy JJ, Weyand CM. Successful and maladaptive T cell aging. Immunity (2017) 46:364-78. doi:10.1016/j.immuni.2017.03.010

8. Fooksman DR, Vardhana S, Vasiliver-Shamis G, Liese J, Blair DA, Waite J, et al. Functional anatomy of $\mathrm{T}$ cell activation and synapse formation. Annu Rev Immunol (2010) 28:79-105. doi:10.1146/annurev-immunol030409-101308

9. Mempel TR, Henrickson SE, Von Andrian UH. T-cell priming by dendritic cells in lymph nodes occurs in three distinct phases. Nature (2004) 427:154-9. doi: $10.1038 /$ nature 02238

10. Arens R, Schoenberger SP. Plasticity in programming of effector and memory CD8 T-cell formation. Immunol Rev (2010) 235:190-205. doi:10.1111/j. 0105-2896.2010.00899.x

11. Curtsinger JM, Mescher MF. Inflammatory cytokines as a third signal for T cell activation. Curr Opin Immunol (2010) 22:333-40. doi:10.1016/j.coi. 2010.02.013

12. Friedman RS, Jacobelli J, Krummel MF. Surface-bound chemokines capture and prime T cells for synapse formation. Nat Immunol (2006) 7:1101-8. doi:10.1038/ni1106-1234a

13. Marsland BJ, Battig P, Bauer M, Ruedl C, Lassing U, Beerli RR, et al. CCL19 and CCL21 induce a potent proinflammatory differentiation program in licensed dendritic cells. Immunity (2005) 22:493-505. doi:10.1016/j.immuni. 2005.02.010

14. Forster R, Davalos-Misslitz AC, Rot A. CCR7 and its ligands: balancing immunity and tolerance. Nat Rev Immunol (2008) 8:362-71. doi:10.1038/nri2297

15. Kaiser A, Donnadieu E, Abastado JP, Trautmann A, Nardin A. CC chemokine ligand 19 secreted by mature dendritic cells increases naive $\mathrm{T}$ cell scanning behavior and their response to rare cognate antigen. J Immunol (2005) 175:2349-56. doi:10.4049/jimmunol.175.4.2349

16. Castellino F, Huang AY, Altan-Bonnet G, Stoll S, Scheinecker C, Germain RN. Chemokines enhance immunity by guiding naive CD8+ T cells to sites of CD4+ T cell-dendritic cell interaction. Nature (2006) 440:890-5. doi:10.1038/ nature 04651

17. Hickman HD, Li L, Reynoso GV, Rubin EJ, Skon CN, Mays JW, et al. Chemokines control naive CD8+ T cell selection of optimal lymph node antigen presenting cells. J Exp Med (2011) 208:2511-24. doi:10.1084/jem.20102545

\section{AUTHOR CONTRIBUTIONS}

All authors contributed to the writing of this review.

\section{FUNDING}

This work was funded by a grant from the European Commission [FP7 Marie Curie Action, Grant number: 316655, VacTrain (SB and RA)].

18. Nolz JC, Starbeck-Miller GR, Harty JT. Naive, effector and memory CD8 T-cell trafficking: parallels and distinctions. Immunotherapy (2011) 3:1223-33. doi:10.2217/imt.11.100

19. Denucci CC, Mitchell JS, Shimizu Y. Integrin function in T-cell homing to lymphoid and nonlymphoid sites: getting there and staying there. Crit Rev Immunol (2009) 29:87-109. doi:10.1615/CritRevImmunol.v29.i2.10

20. Murdoch C, Finn A. Chemokine receptors and their role in inflammation and infectious diseases. Blood (2000) 95:3032-43.

21. Zhang M, Byrne S, Liu N, Wang Y, Oxenius A, Ashton-Rickardt PG. Differential survival of cytotoxic $\mathrm{T}$ cells and memory cell precursors. J Immunol (2007) 178:3483-91. doi:10.4049/jimmunol.178.6.3483

22. Gerlach C, van Heijst JW, Schumacher TN. The descent of memory T cells. Ann N Y Acad Sci (2011) 1217:139-53. doi:10.1111/j.1749-6632.2010.05830.x

23. Sallusto F, Lenig D, Forster R, Lipp M, Lanzavecchia A. Two subsets of memory $\mathrm{T}$ lymphocytes with distinct homing potentials and effector functions. Nature (1999) 401:708-12. doi:10.1038/44385

24. Lefrancois L, Marzo AL. The descent of memory T-cell subsets. Nat Rev Immunol (2006) 6:618-23. doi:10.1038/nri1866

25. Mahnke YD, Brodie TM, Sallusto F, Roederer M, Lugli E. The who's who of T-cell differentiation: human memory T-cell subsets. Eur J Immunol (2013) 43:2797-809. doi:10.1002/eji.201343751

26. Rosenblum MD, Way SS, Abbas AK. Regulatory T cell memory. Nat Rev Immunol (2016) 16:90-101. doi:10.1038/nri.2015.1

27. Pepper M, Jenkins MK. Origins of CD4(+) effector and central memory T cells. Nat Immunol (2011) 12:467-71. doi:10.1038/ni.2038

28. Chang JT, Wherry EJ, Goldrath AW. Molecular regulation of effector and memory T cell differentiation. Nat Immunol (2014) 15:1104-15. doi:10.1038/ ni.3031

29. Masopust D, Schenkel JM. The integration of T cell migration, differentiation and function. Nat Rev Immunol (2013) 13:309-20. doi:10.1038/nri3442

30. Mueller SN, Gebhardt T, Carbone FR, Heath WR. Memory T cell subsets, migration patterns, and tissue residence. Annu Rev Immunol (2013) 31:137-61. doi:10.1146/annurev-immunol-032712-095954

31. Mueller SN, Mackay LK. Tissue-resident memory T cells: local specialists in immune defence. Nat Rev Immunol (2016) 16:79-89. doi:10.1038/nri.2015.3

32. Rosato PC, Beura LK, Masopust D. Tissue resident memory T cells and viral immunity. Curr Opin Virol (2017) 22:44-50. doi:10.1016/j.coviro.2016.11.011

33. Carbone FR. Tissue-resident memory $\mathrm{T}$ cells and fixed immune surveillance in nonlymphoid organs. J Immunol (2015) 195:17-22. doi:10.4049/ jimmunol.1500515

34. Gattinoni L, Lugli E, Ji Y, Pos Z, Paulos CM, Quigley MF, et al. A human memory $\mathrm{T}$ cell subset with stem cell-like properties. Nat Med (2011) 17:1290-7. doi: $10.1038 / \mathrm{nm} .2446$

35. Zhang Y, Joe G, Hexner E, Zhu J, Emerson SG. Host-reactive CD8+ memory stem cells in graft-versus-host disease. Nat Med (2005) 11:1299-305. doi:10.1038/nm1326

36. Gattinoni L, Zhong XS, Palmer DC, Ji Y, Hinrichs CS, Yu Z, et al. Wnt signaling arrests effector T cell differentiation and generates CD8+ memory stem cells. Nat Med (2009) 15:808-13. doi:10.1038/nm.1982

37. Neuenhahn M, Busch DH. The quest for CD8+ memory stem cells. Immunity (2009) 31:702-4. doi:10.1016/j.immuni.2009.10.002

38. Ahmed R, Roger L, Costa Del Amo P, Miners KL, Jones RE, Boelen L, et al. Human stem cell-like memory T cells are maintained in a state of dynamic flux. Cell Rep (2016) 17:2811-8. doi:10.1016/j.celrep.2016.11.037

39. Gattinoni L, Speiser DE, Lichterfeld M, Bonini C. T memory stem cells in health and disease. Nat Med (2017) 23:18-27. doi:10.1038/nm.4241 
40. Freel SA, Lamoreaux L, Chattopadhyay PK, Saunders K, Zarkowsky D, Overman RG, et al. Phenotypic and functional profile of HIV-inhibitory CD8 $\mathrm{T}$ cells elicited by natural infection and heterologous prime/boost vaccination. J Virol (2010) 84:4998-5006. doi:10.1128/JVI.00138-10

41. Maeto C, Rodriguez AM, Holgado MP, Falivene J, Gherardi MM. Novel mucosal DNA-MVA HIV vaccination in which DNA-IL-12 plus cholera toxin B subunit (CTB) cooperates to enhance cellular systemic and mucosal genital tract immunity. PLoS One (2014) 9:e107524. doi:10.1371/journal. pone. 0107524

42. Karrer U, Wagner M, Sierro S, Oxenius A, Hengel H, Dumrese T, et al. Expansion of protective $\mathrm{CD} 8+\mathrm{T}$-cell responses driven by recombinant cytomegaloviruses. J Virol (2004) 78:2255-64. doi:10.1128/JVI.78.5.2255-2264.2004

43. van Duikeren S, Fransen MF, Redeker A, Wieles B, Platenburg G, Krebber WJ, et al. Vaccine-induced effector-memory CD8+ T cell responses predict therapeutic efficacy against tumors. J Immunol (2012) 189:3397-403. doi:10.4049/ jimmunol.1201540

44. Hu Z, Molloy MJ, Usherwood EJ. CD4(+) T-cell dependence of primary CD8(+) T-cell response against Vaccinia virus depends upon route of infection and viral dose. Cell Mol Immunol (2016) 13:82-93. doi:10.1038/cmi.2014.128

45. Wherry EJ. T cell exhaustion. Nat Immunol (2011) 12:492-9. doi:10.1038/ ni. 2035

46. Ogg GS, Jin X, Bonhoeffer S, Dunbar PR, Nowak MA, Monard S, et al. Quantitation of HIV-1-specific cytotoxic T lymphocytes and plasma load of viral RNA. Science (1998) 279:2103-6. doi:10.1126/science.279.5359.2103

47. Davenport MP, Zhang L, Bagchi A, Fridman A, Fu TM, Schleif W, et al. Highpotency human immunodeficiency virus vaccination leads to delayed and reduced CD8+ T-cell expansion but improved virus control. J Virol (2005) 79:10059-62. doi:10.1128/JVI.79.15.10059-10062.2005

48. Mudd PA, Martins MA, Ericsen AJ, Tully DC, Power KA, Bean AT, et al. Vaccine-induced CD8+ T cells control AIDS virus replication. Nature (2012) 491:129-33. doi:10.1038/nature11443

49. Akondy RS, Johnson PL, Nakaya HI, Edupuganti S, Mulligan MJ, Lawson B, et al. Initial viral load determines the magnitude of the human CD8 T cell response to yellow fever vaccination. Proc Natl Acad Sci U S A (2015) 112:3050-5. doi:10.1073/pnas.1500475112

50. Stano A, Nembrini C, Swartz MA, Hubbell JA, Simeoni E. Nanoparticle size influences the magnitude and quality of mucosal immune responses after intranasal immunization. Vaccine (2012) 30:7541-6. doi:10.1016/j. vaccine.2012.10.050

51. Swaminathan G, Thoryk EA, Cox KS, Meschino S, Dubey SA, Vora KA, et al. A novel lipid nanoparticle adjuvant significantly enhances B cell and $\mathrm{T}$ cell responses to sub-unit vaccine antigens. Vaccine (2016) 34:110-9. doi:10.1016/j.vaccine.2015.10.132

52. Billeskov R, Wang Y, Solaymani-Mohammadi S, Frey B, Kulkarni S, Andersen P, et al. Low antigen dose in adjuvant-based vaccination selectively induces CD4 $\mathrm{T}$ cells with enhanced functional avidity and protective efficacy. J Immunol (2017) 198:3494-506. doi:10.4049/jimmunol.1600965

53. Penaloza-MacMaster P, Teigler JE, Obeng RC, Kang ZH, Provine NM, Parenteau L, et al. Augmented replicative capacity of the boosting antigen improves the protective efficacy of heterologous prime-boost vaccine regimens. J Virol (2014) 88:6243-54. doi:10.1128/JVI.00406-14

54. Wu L, Kong WP, Nabel GJ. Enhanced breadth of CD4 T-cell immunity by DNA prime and adenovirus boost immunization to human immunodeficiency virus Env and Gag immunogens. J Virol (2005) 79:8024-31. doi:10.1128/ JVI.79.13.8024-8031.2005

55. Amanna IJ, Slifka MK. Wanted, dead or alive: new viral vaccines. Antiviral Res (2009) 84:119-30. doi:10.1016/j.antiviral.2009.08.008

56. Hanke T, Blanchard TJ, Schneider J, Hannan CM, Becker M, Gilbert SC, et al. Enhancement of MHC class I-restricted peptide-specific T cell induction by a DNA prime/MVA boost vaccination regime. Vaccine (1998) 16:439-45. doi:10.1016/S0264-410X(97)00226-0

57. Brave A, Boberg A, Gudmundsdotter L, Rollman E, Hallermalm K, Ljungberg K, et al. A new multi-clade DNA prime/recombinant MVA boost vaccine induces broad and high levels of HIV-1-specific CD8(+) T-cell and humoral responses in mice. Mol Ther (2007) 15:1724-33. doi:10.1038/ sj.mt. 6300235

58. Amara RR, Villinger F, Altman JD, Lydy SL, O’Neil SP, Staprans SI, et al. Control of a mucosal challenge and prevention of AIDS by a multiprotein DNA/MVA vaccine. Science (2001) 292:69-74. doi:10.1126/science.1058915
59. Barouch DH, Liu J, Li H, Maxfield LF, Abbink P, Lynch DM, et al. Vaccine protection against acquisition of neutralization-resistant SIV challenges in rhesus monkeys. Nature (2012) 482:89-93. doi:10.1038/nature10766

60. Goonetilleke N, Moore S, Dally L, Winstone N, Cebere I, Mahmoud A, et al. Induction of multifunctional human immunodeficiency virus type 1 (HIV-1)-specific T cells capable of proliferation in healthy subjects by using a prime-boost regimen of DNA- and modified Vaccinia virus Ankara-vectored vaccines expressing HIV-1 Gag coupled to CD8+ T-cell epitopes. J Virol (2006) 80:4717-28.

61. Chea LS, Amara RR. Immunogenicity and efficacy of DNA/MVA HIV vaccines in rhesus macaque models. Expert Rev Vaccines (2017) 16:973-85. doi:10.1080/14760584.2017.1371594

62. Borducchi EN, Cabral C, Stephenson KE, Liu J, Abbink P, Ng’ang’a D, et al. Ad26/MVA therapeutic vaccination with TLR7 stimulation in SIV-infected rhesus monkeys. Nature (2016) 540:284-7. doi:10.1038/nature20583

63. Joachim A, Munseri PJ, Nilsson C, Bakari M, Aboud S, Lyamuya EF, et al. Three-year durability of immune responses induced by HIV-DNA and HIVmodified vaccinia virus Ankara and effect of a late HIV-modified vaccinia virus Ankara boost in Tanzanian volunteers. AIDS Res Hum Retroviruses (2017) 33:880-8. doi:10.1089/AID.2016.0251

64. Ewer KJ, O’Hara GA, Duncan CJ, Collins KA, Sheehy SH, Reyes-Sandoval A, et al. Protective CD8+ T-cell immunity to human malaria induced by chimpanzee adenovirus-MVA immunisation. Nat Commun (2013) 4:2836. doi:10.1038/ncomms3836

65. Karrer U, Sierro S, Wagner M, Oxenius A, Hengel H, Koszinowski UH, et al. Memory inflation: continuous accumulation of antiviral CD8+ T cells over time. J Immunol (2003) 170:2022-9. doi:10.4049/jimmunol.170.4.2022

66. O'Hara GA, Welten SP, Klenerman P, Arens R. Memory T cell inflation: understanding cause and effect. Trends Immunol (2012) 33:84-90. doi:10.1016/j. it.2011.11.005

67. Welten SP, Redeker A, Toes RE, Arens R. Viral persistence induces antibody inflation without altering antibody avidity. J Virol (2016) 90:4402-11. doi:10.1128/JVI.03177-15

68. Welten SP, Redeker A, Franken KL, Benedict CA, Yagita H, Wensveen FM, et al. CD27-CD70 costimulation controls $\mathrm{T}$ cell immunity during acute and persistent cytomegalovirus infection. J Virol (2013) 87:6851-65. doi:10.1128/ JVI.03305-12

69. Humphreys IR, Loewendorf A, De TC, Schneider K, Benedict CA, Munks MW, et al. OX40 costimulation promotes persistence of cytomegalovirus-specific CD8 T Cells: a CD4-dependent mechanism. J Immunol (2007) 179:2195-202. doi:10.4049/jimmunol.179.4.2195

70. Hutchinson S, Sims S, O’Hara G, Silk J, Gileadi U, Cerundolo V, et al. A dominant role for the immunoproteasome in $\mathrm{CD} 8+\mathrm{T}$ cell responses to murine cytomegalovirus. PLoS One (2011) 6:e14646. doi:10.1371/journal. pone.0014646

71. Dekhtiarenko I, Jarvis MA, Ruzsics Z, Cicin-Sain L. The context of gene expression defines the immunodominance hierarchy of cytomegalovirus antigens. J Immunol (2013) 190:3399-409. doi:10.4049/jimmunol.1203173

72. Tsuda Y, Caposio P, Parkins CJ, Botto S, Messaoudi I, Cicin-Sain L, et al. A replicating cytomegalovirus-based vaccine encoding a single Ebola virus nucleoprotein CTL epitope confers protection against Ebola virus. PLoS Negl Trop Dis (2011) 5:e1275. doi:10.1371/journal.pntd.0001275

73. Morabito KM, Ruckwardt TR, Redwood AJ, Moin SM, Price DA, Graham BS. Intranasal administration of RSV antigen-expressing MCMV elicits robust tissue-resident effector and effector memory CD8+ T cells in the lung. Mucosal Immunol (2017) 10:545-54. doi:10.1038/mi.2016.48

74. Hansen SG, Sacha JB, Hughes CM, Ford JC, Burwitz BJ, Scholz I, et al. Cytomegalovirus vectors violate $\mathrm{CD} 8+\mathrm{T}$ cell epitope recognition paradigms. Science (2013) 340:1237874. doi:10.1126/science.1237874

75. Hansen SG, Wu HL, Burwitz BJ, Hughes CM, Hammond KB, Ventura AB, et al. Broadly targeted CD8(+) T cell responses restricted by major histocompatibility complex E. Science (2016) 351:714-20. doi:10.1126/science.aac9475

76. Klarenbeek PL, Remmerswaal EB, ten Berge IJ, Doorenspleet ME, van Schaik BD, Esveldt RE, et al. Deep sequencing of antiviral T-cell responses to HCMV and EBV in humans reveals a stable repertoire that is maintained for many years. PLoS Pathog (2012) 8:e1002889. doi:10.1371/journal.ppat.1002889

77. Bolinger B, Sims S, O'Hara G, de Lara C, Tchilian E, Firner S, et al. A new model for CD8+ T cell memory inflation based upon a recombinant adenoviral vector. J Immunol (2013) 190:4162-74. doi:10.4049/jimmunol.1202665 
78. Bolinger B, Sims S, Swadling L, O'Hara G, de Lara C, Baban D, et al. Adenoviral vector vaccination induces a conserved program of CD8(+) T cell memory differentiation in mouse and man. Cell Rep (2015) 13:1578-88. doi:10.1016/j. celrep.2015.10.034

79. Colston JM, Bolinger B, Cottingham MG, Gilbert S, Klenerman P. Modification of antigen impacts on memory quality after adenovirus vaccination. J Immunol (2016) 196:3354-63. doi:10.4049/jimmunol.1502687

80. Barnes E, Folgori A, Capone S, Swadling L, Aston S, Kurioka A, et al. Novel adenovirus-based vaccines induce broad and sustained $\mathrm{T}$ cell responses to $\mathrm{HCV}$ in man. Sci Transl Med (2012) 4:3003155. doi:10.1126/scitranslmed.3003155

81. Moyo N, Borthwick NJ, Wee EG, Capucci S, Crook A, Dorrell L, et al. Long-term follow up of human T-cell responses to conserved HIV-1 regions elicited by DNA/simian adenovirus/MVA vaccine regimens. PLoS One (2017) 12:e0181382. doi:10.1371/journal.pone.0181382

82. Smith C, Tsang J, Beagley L, Chua D, Lee V, Li V, et al. Effective treatment of metastatic forms of Epstein-Barr virus-associated nasopharyngeal carcinoma with a novel adenovirus-based adoptive immunotherapy. Cancer Res (2012) 72:1116-25. doi:10.1158/0008-5472.CAN-11-3399

83. Andersson AC, Holst PJ. Increased T cell breadth and antibody response elicited in prime-boost regimen by viral vector encoded homologous SIV Gag/Env in outbred CD1 mice. J Transl Med (2016) 14:343. doi:10.1186/ s12967-016-1102-7

84. Martins MA, Wilson NA, Reed JS, Ahn CD, Klimentidis YC, Allison DB, et al. T-cell correlates of vaccine efficacy after a heterologous simian immunodeficiency virus challenge. J Virol (2010) 84:4352-65. doi:10.1128/JVI.02365-09

85. Ragonnaud E, Pedersen AG, Holst PJ. Breadth of T cell responses after immunization with adenovirus vectors encoding ancestral antigens or polyvalent papillomavirus antigens. Scand J Immunol (2017) 85:182-90. doi:10.1111/ sji. 12522

86. Filskov J, Mikkelsen M, Hansen PR, Christensen JP, Thomsen AR, Andersen P, et al. Broadening CD4+ and CD8+ T cell responses against hepatitis $\mathrm{C}$ virus by vaccination with NS3 overlapping peptide panels in cross-priming liposomes. J Virol (2017) 91:e00130-17. doi:10.1128/JVI.00130-17

87. Abdel-Hakeem MS, Bedard N, Murphy D, Bruneau J, Shoukry NH. Signatures of protective memory immune responses during hepatitis $\mathrm{C}$ virus reinfection. Gastroenterology (2014) 147:870-81.e8. doi:10.1053/j.gastro.2014.07.005

88. Radebe M, Gounder K, Mokgoro M, Ndhlovu ZM, Mncube Z, Mkhize L, et al. Broad and persistent Gag-specific CD8+ T-cell responses are associated with viral control but rarely drive viral escape during primary HIV-1 infection. AIDS (2015) 29:23-33. doi:10.1097/QAD.0000000000000508

89. Hu X, Valentin A, Dayton F, Kulkarni V, Alicea C, Rosati M, et al. DNA primeboost vaccine regimen to increase breadth, magnitude, and cytotoxicity of the cellular immune responses to subdominant Gag epitopes of simian immunodeficiency virus and HIV. J Immunol (2016) 197:3999-4013. doi:10.4049/ jimmunol.1600697

90. Santra S, Liao HX, Zhang R, Muldoon M, Watson S, Fischer W, et al. Mosaic vaccines elicit CD8+ T lymphocyte responses that confer enhanced immune coverage of diverse HIV strains in monkeys. Nat Med (2010) 16:324-8. doi: $10.1038 / \mathrm{nm} .2108$

91. Barouch DH, O’Brien KL, Simmons NL, King SL, Abbink P, Maxfield LF, et al. Mosaic HIV-1 vaccines expand the breadth and depth of cellular immune responses in rhesus monkeys. Nat Med (2010) 16:319-23. doi:10.1038/nm.2089

92. Che JW, Daniels KA, Selin LK, Welsh RM. Heterologous immunity and persistent murine cytomegalovirus infection. J Virol (2017) 91:e1386-1316. doi:10.1128/JVI.01386-16

93. Price DA, Asher TE, Wilson NA, Nason MC, Brenchley JM, Metzler IS, et al. Public clonotype usage identifies protective Gag-specific CD8+ T cell responses in SIV infection. J Exp Med (2009) 206:923-36. doi:10.1084/ jem.20081127

94. Price DA, West SM, Betts MR, Ruff LE, Brenchley JM, Ambrozak DR, et al. T cell receptor recognition motifs govern immune escape patterns in acute SIV infection. Immunity (2004) 21:793-803. doi:10.1016/j.immuni. 2004.10.010

95. Betts MR, Nason MC, West SM, De Rosa SC, Migueles SA, Abraham J, et al. HIV nonprogressors preferentially maintain highly functional HIV-specific CD8+ T cells. Blood (2006) 107:4781-9. doi:10.1182/blood-2005-12-4818

96. Wijesundara DK, Ranasinghe C, Grubor-Bauk B, Gowans EJ. Emerging targets for developing $\mathrm{T}$ cell-mediated vaccines for human immunodeficiency virus (HIV)-1. Front Microbiol (2017) 8:2091. doi:10.3389/fmicb.2017.02091
97. Zhu J, Yamane H, Paul WE. Differentiation of effector CD4 T cell populations $\left(^{*}\right)$. Annu Rev Immunol (2010) 28:445-89. doi:10.1146/annurevimmunol-030409-101212

98. Stark GR, Kerr IM, Williams BR, Silverman RH, Schreiber RD. How cells respond to interferons. Annu Rev Biochem (1998) 67:227-64. doi:10.1146/ annurev.biochem.67.1.227

99. Seder RA, Darrah PA, Roederer M. T-cell quality in memory and protection: implications for vaccine design. Nat Rev Immunol (2008) 8:247-58. doi:10.1038/nri2274

100. Duvall MG, Precopio ML, Ambrozak DA, Jaye A, McMichael AJ, Whittle HC, et al. Polyfunctional T cell responses are a hallmark of HIV-2 infection. Eur J Immunol (2008) 38:350-63. doi:10.1002/eji.200737768

101. Van Braeckel E, Desombere I, Clement F, Vandekerckhove L, Verhofstede C Vogelaers D, et al. Polyfunctional CD4(+) T cell responses in HIV-1-infected viral controllers compared with those in healthy recipients of an adjuvanted polyprotein HIV-1 vaccine. Vaccine (2013) 31:3739-46. doi:10.1016/j. vaccine.2013.05.021

102. Kannanganat S, Ibegbu C, Chennareddi L, Robinson HL, Amara RR. Multiple-cytokine-producing antiviral CD4 T cells are functionally superior to single-cytokine-producing cells. J Virol (2007) 81:8468-76. doi:10.1128/ JVI.00228-07

103. Schmidt J, Blum HE, Thimme R. T-cell responses in hepatitis B and C virus infection: similarities and differences. Emerg Microbes Infect (2013) 2:e15. doi:10.1038/emi.2013.14

104. Darrah PA, Patel DT, De Luca PM, Lindsay RW, Davey DF, Flynn BJ, et al. Multifunctional TH1 cells define a correlate of vaccine-mediated protection against Leishmania major. Nat Med (2007) 13:843-50. doi:10.1038/nm1592

105. Sridhar S, Begom S, Bermingham A, Hoschler K, Adamson W, Carman W, et al. Cellular immune correlates of protection against symptomatic pandemic influenza. Nat Med (2013) 19:1305-12. doi:10.1038/nm.3350

106. Snyder LD, Chan C, Kwon D, Yi JS, Martissa JA, Copeland CA, et al. Polyfunctional T-cell signatures to predict protection from cytomegalovirus after lung transplantation. Am J Respir Crit Care Med (2016) 193:78-85. doi:10.1164/rccm.201504-0733OC

107. Park SH, Shin EC, Capone S, Caggiari L, De Re V, Nicosia A, et al. Successful vaccination induces multifunctional memory $\mathrm{T}$-cell precursors associated with early control of hepatitis Cvirus. Gastroenterology (2012) 143:1048-60.e4. doi:10.1053/j.gastro.2012.06.005

108. Kim MT, Harty JT. Impact of inflammatory cytokines on effector and memory CD8+ T cells. Front Immunol (2014) 5:295. doi:10.3389/fimmu.2014.00295

109. Almeida JR, Sauce D, Price DA, Papagno L, Shin SY, Moris A, et al. Antigen sensitivity is a major determinant of CD8+ T-cell polyfunctionality and HIV-suppressive activity. Blood (2009) 113:6351-60. doi:10.1182/blood2009-02-206557

110. Precopio ML, Betts MR, Parrino J, Price DA, Gostick E, Ambrozak DR, et al. Immunization with Vaccinia virus induces polyfunctional and phenotypically distinctive CD8(+) T cell responses. J Exp Med (2007) 204:1405-16. doi:10.1084/jem.20062363

111. Ruby J, Bluethmann H, Peschon JJ. Antiviral activity of tumor necrosis factor (TNF) is mediated via p55 and p75 TNF receptors. J Exp Med (1997) 186:1591-6. doi:10.1084/jem.186.9.1591

112. Sedger LM, McDermott MF. TNF and TNF-receptors: from mediators of cell death and inflammation to therapeutic giants - past, present and future. Cytokine Growth Factor Rev (2014) 25:453-72. doi:10.1016/j. cytogfr.2014.07.016

113. Wohlleber D, Kashkar H, Gartner K, Frings MK, Odenthal M, Hegenbarth S, et al. TNF-induced target cell killing by CTL activated through crosspresentation. Cell Rep (2012) 2:478-87. doi:10.1016/j.celrep.2012.08.001

114. Paludan SR. Synergistic action of pro-inflammatory agents: cellular and molecular aspects. J Leukoc Biol (2000) 67:18-25. doi:10.1002/jlb.67.1.18

115. Williams MA, Tyznik AJ, Bevan MJ. Interleukin-2 signals during priming are required for secondary expansion of CD8+ memory T cells. Nature (2006) 441:890-3. doi:10.1038/nature04790

116. Liao W, Lin JX, Leonard WJ. Interleukin-2 at the crossroads of effector responses, tolerance, and immunotherapy. Immunity (2013) 38:13-25. doi:10.1016/j.immuni.2013.01.004

117. Feau S, Arens R, Togher S, Schoenberger SP. Autocrine IL-2 is required for secondary population expansion of CD8(+) memory T cells. Nat Immunol (2011) 12:908-13. doi:10.1038/ni.2079 
118. Bachmann MF, Wolint P, Walton S, Schwarz K, Oxenius A. Differential role of IL-2R signaling for CD8+ T cell responses in acute and chronic viral infections. Eur J Immunol (2007) 37:1502-12. doi:10.1002/eji.200637023

119. Cox MA, Harrington LE, Zajac AJ. Cytokines and the inception of CD8 T cell responses. Trends Immunol (2011) 32:180-6. doi:10.1016/j.it.2011.01.004

120. Redeker A, Welten SP, Baert MR, Vloemans SA, Tiemessen MM, Staal FJ, et al. The quantity of autocrine IL-2 governs the expansion potential of CD8+ T cells. J Immunol (2015) 195:4792-801. doi:10.4049/jimmunol.1501083

121. Janas ML, Groves P, Kienzle N, Kelso A. IL-2 regulates perforin and granzyme gene expression in CD8+ T cells independently of its effects on survival and proliferation. JImmunol (2005) 175:8003-10. doi:10.4049/ jimmunol.175.12.8003

122. Pipkin ME, Rao A, Lichtenheld MG. The transcriptional control of the perforin locus. Immunol Rev (2010) 235:55-72. doi:10.1111/j.0105-2896.2010.00905.x

123. Kalia V, Sarkar S, Subramaniam S, Haining WN, Smith KA, Ahmed R. Prolonged interleukin-2Ralpha expression on virus-specific CD8+ T cells favors terminal-effector differentiation in vivo. Immunity (2010) 32:91-103. doi:10.1016/j.immuni.2009.11.010

124. Kehrl JH, Dukovich M, Whalen G, Katz P, Fauci AS, Greene WC. Novel interleukin 2 (IL-2) receptor appears to mediate IL-2-induced activation of natural killer cells. J Clin Invest (1988) 81:200-5. doi:10.1172/JCI113295

125. Lee SH, Fragoso MF, Biron CA. Cutting edge: a novel mechanism bridging innate and adaptive immunity: IL-12 induction of CD25 to form high-affinity IL-2 receptors on NK cells. J Immunol (2012) 189:2712-6. doi:10.4049/ jimmunol.1201528

126. Wu Z, Frascaroli G, Bayer C, Schmal T, Mertens T. Interleukin-2 from adaptive $\mathrm{T}$ cells enhances natural killer cell activity against human cytomegalovirus-infected macrophages. J Virol (2015) 89:6435-41. doi:10.1128/ JVI.00435-15

127. Croft M. Co-stimulatory members of the TNFR family: keys to effective T-cell immunity? Nat Rev Immunol (2003) 3:609-20. doi:10.1038/nril148

128. Welten SP, Melief CJ, Arens R. The distinct role of T cell costimulation in antiviral immunity. Curr Opin Virol (2013) 3:475-82. doi:10.1016/j. coviro.2013.06.012

129. van der Windt GJ, Pearce EL. Metabolic switching and fuel choice during T-cell differentiation and memory development. Immunol Rev (2012) 249:27-42. doi:10.1111/j.1600-065X.2012.01150.x

130. Buck MD, O'Sullivan D, Pearce EL. T cell metabolism drives immunity. J Exp Med (2015) 212:1345-60. doi:10.1084/jem.20151159

131. Maclver NJ, Michalek RD, Rathmell JC. Metabolic regulation of T lymphocytes. Annu Rev Immunol (2013) 31:259-83. doi:10.1146/ annurev-immunol-032712-095956

132. Patel CH, Powell JD. Targeting $\mathrm{T}$ cell metabolism to regulate $\mathrm{T}$ cell activation, differentiation and function in disease. Curr Opin Immunol (2017) 46:82-8. doi:10.1016/j.coi.2017.04.006

133. Pollizzi KN, Powell JD. Regulation of T cells by mTOR: the known knowns and the known unknowns. Trends Immunol (2015) 36:13-20. doi:10.1016/j. it.2014.11.005

134. Araki K, Turner AP, Shaffer VO, Gangappa S, Keller SA, Bachmann MF, et al. mTOR regulates memory CD8 T-cell differentiation. Nature (2009) 460:108-12. doi:10.1038/nature08155

135. Pollizzi KN, Patel CH, Sun IH, Oh MH, Waickman AT, Wen J, et al. mTORC1 and mTORC2 selectively regulate CD8(+) T cell differentiation. J Clin Invest (2015) 125:2090-108. doi:10.1172/JCI77746

136. Sukumar M, Liu J, Ji Y, Subramanian M, Crompton JG, Yu Z, et al. Inhibiting glycolytic metabolism enhances CD8+ T cell memory and antitumor function. JClin Invest (2013) 123:4479-88. doi:10.1172/JCI69589

137. van der Windt GJ, O'Sullivan D, Everts B, Huang SC, Buck MD, Curtis JD, et al. CD8 memory T cells have a bioenergetic advantage that underlies their rapid recall ability. Proc Natl Acad Sci U S A (2013) 110:14336-41. doi:10.1073/pnas.1221740110

138. Buck MD, O'Sullivan D, Klein Geltink RI, Curtis JD, Chang CH, Sanin DE, et al. Mitochondrial dynamics controls T cell fate through metabolic programming. Cell (2016) 166:63-76. doi:10.1016/j.cell.2016.05.035

139. Bengsch B, Johnson AL, Kurachi M, Odorizzi PM, Pauken KE, Attanasio J, et al. Bioenergetic insufficiencies due to metabolic alterations regulated by the inhibitory receptor PD-1 are an early driver of CD8(+) T cell exhaustion. Immunity (2016) 45:358-73. doi:10.1016/j.immuni.2016.07.008
140. Austin S, St-Pierre J. PGClalpha and mitochondrial metabolism emerging concepts and relevance in ageing and neurodegenerative disorders. J Cell Sci (2012) 125:4963-71. doi:10.1242/jcs.113662

141. Scharping NE, Menk AV, Moreci RS, Whetstone RD, Dadey RE, Watkins SC, et al. The tumor microenvironment represses $\mathrm{T}$ cell mitochondrial biogenesis to drive intratumoral $\mathrm{T}$ cell metabolic insufficiency and dysfunction. Immunity (2016) 45:374-88. doi:10.1016/j.immuni.2016.07.009

142. Nakaya M, Xiao Y, Zhou X, Chang JH, Chang M, Cheng X, et al. Inflammatory $\mathrm{T}$ cell responses rely on amino acid transporter ASCT2 facilitation of glutamine uptake and mTORC1 kinase activation. Immunity (2014) 40:692-705. doi:10.1016/j.immuni.2014.04.007

143. Sinclair LV, Rolf J, Emslie E, Shi YB, Taylor PM, Cantrell DA. Control of amino-acid transport by antigen receptors coordinates the metabolic reprogramming essential for T cell differentiation. Nat Immunol (2013) 14:500-8. doi:10.1038/ni.2556

144. Li S, Sullivan NL, Rouphael N, Yu T, Banton S, Maddur MS, et al. Metabolic phenotypes of response to vaccination in humans. Cell (2017) 169:862-77. doi:10.1016/j.cell.2017.04.026

145. Duttagupta PA, Boesteanu AC, Katsikis PD. Costimulation signals for memory CD8+ T cells during viral infections. Crit Rev Immunol (2009) 29:469-86. doi:10.1615/CritRevImmunol.v29.16.20

146. Chen L, Flies DB. Molecular mechanisms of T cell co-stimulation and coinhibition. Nat Rev Immunol (2013) 13:227-42. doi:10.1038/nri3405

147. Welten SP, Redeker A, Franken KL, Oduro JD, Ossendorp F, Cicin-Sain L, et al. The viral context instructs the redundancy of costimulatory pathways in driving CD8(+) T cell expansion. Elife (2015) 4:e07486. doi:10.7554/ eLife.07486

148. Zhao Y, Tahiliani V, Salek-Ardakani S, Croft M. Targeting 4-1BB (CD137) to enhance $\mathrm{CD} 8 \mathrm{~T}$ cell responses with poxviruses and viral antigens. Front Immunol (2012) 3:332. doi:10.3389/fimmu.2012.00332

149. Vezys V, Penaloza-MacMaster P, Barber DL, Ha SJ, Konieczny B, Freeman GJ, et al. 4-1BB signaling synergizes with programmed death ligand 1 blockade to augment CD8 T cell responses during chronic viral infection. J Immunol (2011) 187:1634-42. doi:10.4049/jimmunol.1100077

150. Kim YH, Seo SK, Choi BK, Kang WJ, Kim CH, Lee SK, et al. 4-1BB costimulation enhances HSV-1-specific CD8+ T cell responses by the induction of CD11c+CD8+ T cells. Cell Immunol (2005) 238:76-86. doi:10.1016/j. cellimm.2006.01.004

151. Croft M. The role of TNF superfamily members in T-cell function and diseases. Nat Rev Immunol (2009) 9:271-85. doi:10.1038/nri2526

152. Waller EC, McKinney N, Hicks R, Carmichael AJ, Sissons JG, Wills MR. Differential costimulation through CD137 (4-1BB) restores proliferation of human virus-specific "effector memory" (CD28(-) CD45RA(HI)) CD8(+) T cells. Blood (2007) 110:4360-6. doi:10.1182/blood-2007-07-104604

153. Panagioti E, Boon L, Arens R, van der Burg SH. Enforced OX40 stimulation empowers booster vaccines to induce effective CD4+ and CD8+ $\mathrm{T}$ cell responses against mouse cytomegalovirus infection. Front Immunol (2017) 8:144. doi:10.3389/fimmu.2017.00144

154. Bartholdy C, Kauffmann SO, Christensen JP, Thomsen AR. Agonistic anti-CD40 antibody profoundly suppresses the immune response to infection with lymphocytic choriomeningitis virus. J Immunol (2007) 178:1662-70. doi:10.4049/jimmunol.178.3.1662

155. Watts TH. TNF/TNFR family members in costimulation of $\mathrm{T}$ cell responses. Annu Rev Immunol (2005) 23:23-68. doi:10.1146/annurev.immunol.23. 021704.115839

156. Kanagavelu S, Termini JM, Gupta S, Raffa FN, Fuller KA, Rivas Y, et al. HIV-1 adenoviral vector vaccines expressing multi-trimeric BAFF and 4-1BBL enhance T cell mediated anti-viral immunity. PLoS One (2014) 9:e90100. doi:10.1371/journal.pone. 0090100

157. Ahlers JD, Belyakov IM. Memories that last forever: strategies for optimizing vaccine T-cell memory. Blood (2010) 115:1678-89. doi:10.1182/blood2009-06-227546

158. Bukczynski J, Wen T, Wang C, Christie N, Routy JP, Boulassel MR, et al. Enhancement of HIV-specific CD8 T cell responses by dual costimulation with CD80 and CD137L. JImmunol (2005) 175:6378-89. doi:10.4049/ jimmunol.175.10.6378

159. Laderach D, Movassagh M, Johnson A, Mittler RS, Galy A. 4-1BB costimulation enhances human $\mathrm{CD} 8(+) \mathrm{T}$ cell priming by augmenting the 
proliferation and survival of effector CD8(+) T cells. Int Immunol (2002) 14:1155-67. doi:10.1093/intimm/dxf080

160. Halstead ES, Mueller YM, Altman JD, Katsikis PD. In vivo stimulation of CD137 broadens primary antiviral CD8+ T cell responses. Nat Immunol (2002) 3:536-41. doi:10.1038/ni798

161. Barber DL, Wherry EJ, Masopust D, Zhu B, Allison JP, Sharpe AH, et al. Restoring function in exhausted CD8 T cells during chronic viral infection. Nature (2006) 439:682-7. doi:10.1038/nature04444

162. Velu V, Titanji K, Zhu B, Husain S, Pladevega A, Lai L, et al. Enhancing SIV-specific immunity in vivo by PD-1 blockade. Nature (2009) 458:206-10. doi:10.1038/nature 07662

163. Fuller MJ, Callendret B, Zhu B, Freeman GJ, Hasselschwert DL, Satterfield W, et al. Immunotherapy of chronic hepatitis $\mathrm{C}$ virus infection with antibodies against programmed cell death-1 (PD-1). Proc Natl Acad Sci U S A (2013) 110:15001-6. doi:10.1073/pnas.1312772110

164. Larkin J, Chiarion-Sileni V, Gonzalez R, Grob JJ, Cowey CL, Lao CD, et al. Combined nivolumab and ipilimumab or monotherapy in untreated melanoma. N Engl J Med (2015) 373:23-34. doi:10.1056/NEJMoa1504030

165. Karaki S, Anson M, Tran T, Giusti D, Blanc C, Oudard S, et al. Is there still room for cancer vaccines at the era of checkpoint inhibitors. Vaccines (Basel) (2016) 4:37. doi:10.3390/vaccines4040037

166. Liu J, Zhang E, Ma Z, Wu W, Kosinska A, Zhang X, et al. Enhancing virus-specific immunity in vivo by combining therapeutic vaccination and PD-L1 blockade in chronic hepadnaviral infection. PLoS Pathog (2014) 10:e1003856. doi:10.1371/journal.ppat.1003856

167. Finnefrock AC, Tang A, Li F, Freed DC, Feng M, Cox KS, et al. PD-1 blockade in rhesus macaques: impact on chronic infection and prophylactic vaccination. J Immunol (2009) 182:980-7. doi:10.4049/jimmunol.182.2.980

168. Yuan J, Ginsberg B, Page D, Li Y, Rasalan T, Gallardo HF, et al. CTLA-4 blockade increases antigen-specific CD8(+) $\mathrm{T}$ cells in prevaccinated patients with melanoma: three cases. Cancer Immunol Immunother (2011) 60:1137-46. doi:10.1007/s00262-011-1011-9

169. Hixon JA, Blazar BR, Anver MR, Wiltrout RH, Murphy WJ. Antibodies to CD40 induce a lethal cytokine cascade after syngeneic bone marrow transplantation. Biol Blood Marrow Transplant (2001) 7:136-43. doi:10.1053/ bbmt.2001.v7.pm11302547

170. Niu L, Strahotin S, Hewes B, Zhang B, Zhang Y, Archer D, et al. Cytokinemediated disruption of lymphocyte trafficking, hemopoiesis, and induction of lymphopenia, anemia, and thrombocytopenia in anti-CD137-treated mice. J Immunol (2007) 178:4194-213. doi:10.4049/jimmunol.178.7.4194

171. Khan U, Ali F, Khurram MS, Zaka A, Hadid T. Immunotherapy-associated autoimmune hemolytic anemia. JImmunother Cancer (2017) 5:15. doi:10.1186/s40425-017-0214-9

172. Frauwirth KA, Riley JL, Harris MH, Parry RV, Rathmell JC, Plas DR, et al. The CD28 signaling pathway regulates glucose metabolism. Immunity (2002) 16:769-77. doi:10.1016/S1074-7613(02)00323-0
173. Chang CH, Curtis JD, Maggi LB Jr, Faubert B, Villarino AV, O'Sullivan D, et al. Posttranscriptional control of $\mathrm{T}$ cell effector function by aerobic glycolysis. Cell (2013) 153:1239-51. doi:10.1016/j.cell.2013.05.016

174. Macintyre AN, Gerriets VA, Nichols AG, Michalek RD, Rudolph MC, Deoliveira D, et al. The glucose transporter Glut1 is selectively essential for CD4 T cell activation and effector function. Cell Metab (2014) 20:61-72. doi:10.1016/j.cmet.2014.05.004

175. Wang R, Dillon CP, Shi LZ, Milasta S, Carter R, Finkelstein D, et al. The transcription factor Myc controls metabolic reprogramming upon T lymphocyte activation. Immunity (2011) 35:871-82. doi:10.1016/j.immuni.2011.09.021

176. Patsoukis N, Bardhan K, Chatterjee P, Sari D, Liu B, Bell LN, et al. PD-1 alters T-cell metabolic reprogramming by inhibiting glycolysis and promoting lipolysis and fatty acid oxidation. Nat Commun (2015) 6:6692. doi:10.1038/ncomms7692

177. Kawalekar OU, O’Connor RS, Fraietta JA, Guo L, McGettigan SE, Posey AD Jr, et al. Distinct signaling of coreceptors regulates specific metabolism pathways and impacts memory development in CAR T cells. Immunity (2016) 44:380-90. doi:10.1016/j.immuni.2016.01.021

178. Choi BK, Lee DY, Lee DG, Kim YH, Kim SH, Oh HS, et al. 4-1BB signaling activates glucose and fatty acid metabolism to enhance $\mathrm{CD} 8+\mathrm{T}$ cell proliferation. Cell Mol Immunol (2017) 14:748-57. doi:10.1038/cmi.2016.02

179. June CH, Ledbetter JA, Gillespie MM, Lindsten T, Thompson CB. T-cell proliferation involving the $\mathrm{CD} 28$ pathway is associated with cyclosporineresistant interleukin 2 gene expression. Mol Cell Biol (1987) 7:4472-81. doi:10.1128/MCB.7.12.4472

180. Peperzak V, Xiao Y, Veraar EA, Borst J. CD27 sustains survival of CTLs in virus-infected nonlymphoid tissue in mice by inducing autocrine IL-2 production. J Clin Invest (2010) 120:168-78. doi:10.1172/JCI40178

181. Oh HS, Choi BK, Kim YH, Lee DG, Hwang S, Lee MJ, et al. 4-1BB signaling enhances primary and secondary population expansion of $\mathrm{CD} 8+\mathrm{T}$ cells by maximizing autocrine IL-2/IL-2 receptor signaling. PLoS One (2015) 10:e0126765. doi:10.1371/journal.pone.0126765

182. Tan MP, Gerry AB, Brewer JE, Melchiori L, Bridgeman JS, Bennett AD, et al. $T$ cell receptor binding affinity governs the functional profile of cancer-specific CD8+ T cells. Clin Exp Immunol (2015) 180:255-70. doi:10.1111/cei.12570

Conflict of Interest Statement: The authors declare that the research was conducted in the absence of any commercial or financial relationships that could be construed as a potential conflict of interest.

Copyright $\odot 2018$ Panagioti, Klenerman, Lee, van der Burg and Arens. This is an open-access article distributed under the terms of the Creative Commons Attribution License (CC BY). The use, distribution or reproduction in other forums is permitted, provided the original author(s) and the copyright owner are credited and that the original publication in this journal is cited, in accordance with accepted academic practice. No use, distribution or reproduction is permitted which does not comply with these terms. 